\title{
ORIGINAL
}

\section{The protostylid on teeth of Malawians, and the Mongoloid dental complex}

\author{
Masashi Sakuma and Takahiko Ogata \\ (Chief: Prof. T. Ogata) \\ Department of Oral Anatomy, Kagoshima University Dental \\ School, 1208-1 Usuki-cho, Kagoshima 890, Japan
}

[Accepted for publication: June 29, 1987]

\begin{abstract}
Key words: Protostylid/racial traits / African Negroes/Mongoloid dental complex
\end{abstract}
\begin{abstract}
The protostylid among the Malawians residing in East-Central Africa was examined and classified using Dahlberg's standard plaque. The occurrence of the protorstylid as an actual cusp was not found at all on first and second lower molars. This result is accordance with the finding on first lower molars in American Negroes. Therefore, the population derived from Negroid racial stock seems to have less potentiality for expressing the protostylid than do other races. Hanihara mentioned that it might be better to be put the protostylid outside of the "Mongoloid dental complex" in the permanent dentition. However, taking into consideration the fact that Caucasoid-derived groups have a considerably lower frequency of the trait than do Mongoloid-derived groups, it is rather appropriate for the protostylid to be included as one component of the "Mongoloid dental complex" in the permanent dentition.
\end{abstract}

\section{Introduction}

Bolk $^{11}$ has described supernumerary cusps occurring on the buccal surfaces of second and third molars, which he called paramolar cusps. He concluded that these cusps were atavistic remnants of lost posterior teeth of the deciduous dentition. It had been considered that paramolar cusps were never found on the permanent first molar, because this tooth was regarded as belonging to the deciduous series. However, Dahlberg ${ }^{2}$ found such cusps on first lower molars of (1) a skull in the New Britain Melanesian collection at the Chicago Natural History Museum, (2) a skull in a similar collection at the U.S. National Museum, and (3) a living Caucasian female. Therefore, Bolk's concept proved to be wrong. Dahlberg has applied the term "paramolar cusp" to any stylar or anomalous cusp, supernumerary inclusion or eminence occurring on the buccal surfaces of both upper and lower premolars and molars. Of this general group of paramolar cusps, he also distingished the particular cusps, the protostylids restricted to the mesial part of the buccal surfaces of lower molars. According to Dahlberg's definition ${ }^{3)}$, the protostylid, which ascends from the gingival end of the buccal groove and extends mesio-occlusally, is an elevation or ridge of enamel on the anterior part of the buccal surface of the protoconid in the mandibular molars. This trait has often been found among fossil material $^{4-5)}$. It was accordingly assumed to be an ancestral character specialized from the mesial part of cingulum.

Later on, Hanihara ${ }^{6)}$ reported in study of the deciduous dentition that the occurrence of the protostylid was observed more frequently in Mongoloid populations than done in the American Negroes and Caucasians. Thus, this extra-cusp should be included as one component of the "Mongoloid dental complex" in the deciduous dentition. Unfortunately, no available investigation of the pureblooded Negroid population has been carried out with respect to the protostylid complex 
so far.

The purpose of this communication is:

1) To determine the frequency of the protostylid complex among the Malawians derived from the African Negroid racial stock.

2) To re-evaluate the protostylid as a part of the "Mongoloid dental complex" based on the above data.

\section{Materials and Methods}

The subjects were 190 individuals (98 males and 92 females) from Malawians, residing in East-Central Africa. The data were obtained from observation on full-mouth dental hard plaster casts. A detailed description of the Malawian sample was reported previously ${ }^{7}$.

The frequency and degree of expression of the protostylid were observed on the first and second lower molars. Scoring was performed on the teeth of the right side, and those of the left side were used only to fill in missing right side data. Classification of the protostylid was made according to the grading developed by Dahlberg ${ }^{8)}$ :

Grade 0 : No evidence of protostylid.
Grade 1:Pit at inferior end of buccal groove or on buccal surface of the protoconid.

Grade 2 : Distal deviation of mesiobuccal groove.

Grade 3 : Marked deviation of mesiobuccal groove plus a faint surface alteration suggesting the protostylid.

Grade 4 and Grade 5 : Increasingly pronounced expression of the protostylid as a definite cusp.

This system offers the most thorough and complete analysis of the protostylid and is useful for comparative purposes. His categories can be easily reduced by combining some of the groups, which allows further comparison with studies using different classifications.

Dahlberg's standard plaque P-13 (Fig. 1) was used as references in determining the classification of the protostylid. All casts available in this study were observed and classified by one of the authors (M. Sakuma), and particular care was taken in the observation of low grade expressions. The chisquare test was applied to the data analysis in sexual dimorphism.

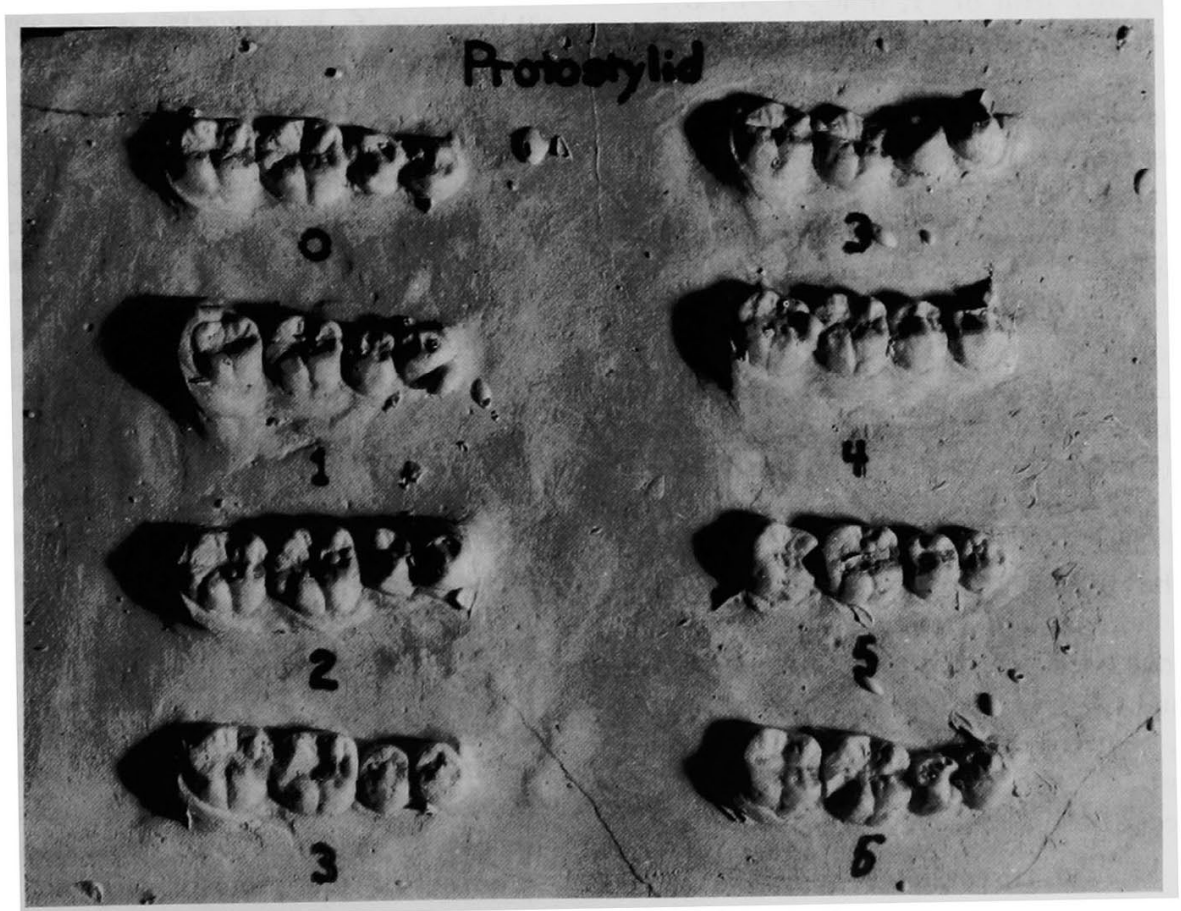

Fig. 1 Variation of the protostylid (Dahlberg's plaque P-13). 
Table 1 Expressions of the protostylid in the Malawians Negroes

\begin{tabular}{|c|c|c|c|c|c|c|c|c|c|}
\hline \multirow{2}{*}{ Sex } & \multirow{2}{*}{$\begin{array}{c}\text { Grade } \\
\mathrm{N}\end{array}$} & \multicolumn{2}{|c|}{0} & \multicolumn{2}{|c|}{1} & \multicolumn{2}{|c|}{2} & \multicolumn{2}{|c|}{$3-5$} \\
\hline & & $\mathrm{n}$ & $\%$ & $\mathrm{n}$ & $\%$ & $\mathrm{n}$ & $\%$ & $\mathrm{n}$ & $\%$ \\
\hline & & \multicolumn{8}{|c|}{ First lower molar } \\
\hline Male & 98 & 87 & $(88.8)$ & 9 & $(9.2)$ & 2 & $(2.0)$ & 0 & $(0.0)$ \\
\hline Female & 92 & 83 & $(90.2)$ & 8 & $(8.7)$ & 1 & $(1.1)$ & 0 & $(0.0)$ \\
\hline \multirow[t]{2}{*}{ Total } & 190 & 170 & $(89.5)$ & 17 & $(8.9)$ & 3 & $(1.6)$ & 0 & $(0.0)$ \\
\hline & & \multicolumn{8}{|c|}{ Second lower molar } \\
\hline Male & 97 & 88 & $(90.7)$ & 7 & $(7.2)$ & 2 & $(2.1)$ & 0 & $(0.0)$ \\
\hline Female & 92 & 87 & $(94.6)$ & 5 & $(5.4)$ & 0 & $(0.0)$ & 0 & $(0.0)$ \\
\hline Total & 189 & 175 & $(92.6)$ & 12 & $(6.3)$ & 2 & $(1.1)$ & 0 & $(0.0)$ \\
\hline
\end{tabular}

Classfication is adapted from Dahlberg, A. A. (1963).

$\mathrm{N}$ : Total number of teeth examined.

$\mathrm{n}$ : Number of teeth demonstrating indicated degree of expression.

\section{Results}

Table 1 depicts the distribution of the different phenotypic grades of expression of the protostylid in the Malawians with sexes separated. The absence of sexual dimorphism of the trait in both lower molars was shown by the lack of statistically significant difference between its incidence in males and females (M1, $\chi^{2}=0.105$ with $\mathrm{df}=1,0.80>\mathrm{P}>0.70$; $\mathrm{M} 2, \chi^{2}=1.017$ with $\mathrm{df}=1,0.40>\mathrm{P}>0.30$ ).

The protostylid complex was only found to manifest itself as lower grades. The complete absence of the protostylid (Grade 0) was most frequently observed among samples, exhibiting $89.5 \%$ on first lower molars and $92.6 \%$ on second lower molars, respectively. No protostylid as an acutual cusp (Grade 3, Grade 4, and Grade 5) was recognized on either lower molars. The frequency of teeth possessing the pit at the inferior end of the buccal groove or buccal surface of the protoconid (Grade 1) was $8.9 \%$ on first lower molars and $6.3 \%$ on second lower molars, respectively. Carious teeth were excluded from the present analysis, as a matter of course. The distal deviation of the mesiobuccal groove (Grade 2) was rarely found, being $1.6 \%$ and $1.1 \%$ in the first and second lower molars, respectively. In short, no example of a cusp, of any size, occurred on the first and second lower molars.

\section{Discussion}

The frequency of each grade in the males slightly exceeds that in the females. This tendency agrees with findings by several authors $^{9-12)}$ except for Turner and Hanihara ${ }^{13)}$. As was already described, there was no significant difference of sexual dimorphism on both lower molars in the Malawian samples.

Unfortunately, markedly different trait frequencies have been reported for samples from the same geographic region. In Japanese, the frequency of occurrence of the protostylid ranges from $0.97 \%^{10)}$ to $42.38 \%^{11}$ on first lower molars and from $0.97 \%^{10}$ to $15.61 \%^{11}$ on second lower molars. It is likely that these differences, to a large part, reflect methods of observation and classification rather than actual intergroup variation. Therefore, reliable comparisons between different samples can be made only on the evidence of a dental trait which has been scored by the same criteria for classification. According to Dahlberg ${ }^{8}$, the pit at inferior end of buccal groove or buccal surface of the protoconid (Grade 1) and the distal deviation of mesiobuccal groove (Grade 2) were regarded as continuous variable degrees expressing the protostylid, and these two types were accordingly included in his classification. On the contrary, Kikuchi ${ }^{11}$ pointed out in the morphological study of enamel-dentin border on the buccal surface of lower molars that the so-called pit and distal deviation types should be excluded from the degrees of expression of the protostylid. From what has been said above, two results regarding the 
total frequency of this feature in Malawians can be extracted. On the basis of the original criteria developed by Dahlberg, the total frequency of appearance of the protostylid is $10.5 \%$ on first lower molars and $7.4 \%$ on second lower molars. However, when following the Kikuchi's opinion, neither lower molars possess this trait.

Quite recently, Sakai ${ }^{14)}$ has compiled total frequencies of the protostylid on several different populations reported in the dental literature for the past decade. In his data the so-called pit and distal deviation types have been omitted from the calculation of total frequencies. Consequently, his criteria happen to coincide with those of Kikuchi. For a comparison of these data with those of the Malawian material, the values from Grade 3 to Grade 5 by the Dahlberg's classification were summed up ( $\mathrm{Ml} ; 0.0 \%, \mathrm{M} 2 ; 0.0 \%)$. On the basis of the table constructed by Sakai $^{14)}$, contrasting the total frequency of the protostylid on first lower molars of several populations, the frequency of Malawians in the present paper appears to show slightly lower than that of Caucasoid populations (e.g. Caucasians ; $1.0 \%$, Afghans ; $2.5 \%$ ), and considerably lower than that of Mongoloid racial groups (e.g. American Indians; $23.6 \%$, Japanese ; $14.3 \%$, Ainu ; $8.4 \%$ ). With second lower molars, the available information is quite small. The Caucasoid population has been investigated only by Dahlberg ${ }^{8}$ (American Whites ; $2.2 \%$ ), and the Mongoloid frequency was more than $3.0 \%$ (Peruvian Indians) ${ }^{15)}$ at the lowest. By comparison with the data from the Malawian sample, the frequency of Malawians as to occurrence of the protostylid on the second lower molars was obviously lower than that of the Caucasoid and Mongoloid populations.

Hanihara ${ }^{16)}$ mentioned that the protostylid might be better to be put outside of the "Mongoloid dental complex" in the permanent dentition; the evidence of the trait was not so remarkably different among the Japanese, American Negroes and Caucasians, although the general trend was basically the same as that in the deciduous dentition. However, judging from above-described facts and the absence of a protostylid, as an actual cusp in American Negroes ${ }^{16)}$, the population derived from Negroid racial stock seems to have less potentiality for expressing the protostylid than do other races. On the other hand, Sakai ${ }^{14}$ reported that the protostylid on the first lower molar was much more frequently found among several Mongoloid populations than among Caucasians and Afghans derived from Caucasoid racial stock. Therefore, it is rather appropriate that the protostylid is includ. ed as one component of the "Mongoloid dental complex" in the permanent dentition. In addition, frequency data of American Whites and Peruvian Indians on the second lower molars, and of American Negroes on the first lower molars are values which excluded the pit and distal deviation types.

\section{Acknowledgements}

The authors are deeply indebted to Dr. Toshiaki Arimatsu, the Head of the Dental Department, Zomba General Hospital, Zomba, Malawi, for his kind provision of the materials and for his encouragement. This work was supported in part by a Grant for Encouragement of Young Scientists from the Ministry of Education of Japan.

\footnotetext{
抄録 : Dahlberg の基準模型をもとに，中東アフリカに位置するマラウィ共和国住民の Protostylid に ついてその出現率を調査した。明らかな結節状を示すタイプの Protostylid は, 下顎第 1 , 第 2 大臼歯い ずれにも認められなかった。これは, アメリカ黒人資料における下顎第 1 大臼歯の所見と一致する。従 って, 黒色系人種に由来する集団は他の人種と比較して, Protostylid の発現力が低いと解釈できるかも 知れない。永久霆に関しては, Protostylid “ “Mongoloid dental complex”の構成要素から除外する 考え方もあるが, 白色系人種が蒙古系人種に比べ, 明らかに Protostylid の出現頻度が低い值を示すこ となどを考え合わせると，Protostylid “ “Mongoloid dental complex”の構成要素に加える方が，む しろ妥当であると考えられる。
} 


\section{References}

1) Bolk, L.: Problems of human dentition. Am. J. Anat. 19 : 91-148, 1916.

2) Dahlberg, A. A.: The paramolar tubercle (Bolk). Am. J. Phys. Anthropol. 3 : 97-103, 1945.

3) Dahlberg, A. A.: The evolutionary significance of the protostylid. Am. J. Phys. Anthropol. $8: 15-24,1950$.

4) Weidenreich, F.: The dentition of Sinanthropus pekinensis; A comparative odontography of hominids. Palaeontol. Sin., n. s. D (1), 1937.

5) Weidenreich, F.: Giant early man from Java and South China. Anthropol. Pap. Am. Mus. Nat. Hist. $40: 1-135,1945$

6) Hanihara, K. : Mongoloid dental complex in the deciduous dentition. J. Anthropol. Soc. Nippon 74:61-72, 1966.

7) Sakuma, M. and Ogata, T.: Sixth and seventh cusp on lower molar teeth of Malawians in East-Central Africa. Jpn. J. Oral Biol. 29 : 738-745, 1987.

8) Dahlberg, A. A. : Analysis of the American Indian dentition, In : Dental Anthropology (edited by Brothwell, D. R.), pp. 149-177, Pergamon Press, Oxford, 1963.

9) Sumiya, Y.: Statistic study on dental anomalies in the Japanese. J. Anthropol. Soc.
Nippon 67 : 215-233, 1959 (In Japanese with English summary).

10) Onda, S. and Minemura, R. : The evolution of the protostylid and buccal pit on the lower molars in the Japanese. The Matsumoto Shigaku 2 : 28-36, 1976 (In Japanese with English summary).

11) Kikuchi, M.: The protostylid of the lower molar row in Japanese. Tohoku Univ. Dent. J. 4 : 185-196, 1985 (In Japanese).

12) Kubota, K., Tsuruoka, Y., Kouyama, C. and Ozaki; T.: A study on dental anomalies among primary school pupils upper and lower lst molars (Part IV). Nihon Univ. J. oral Sci. 12: 142-148, 1986 (In Japanese with English abstract).

13) Turner, C. G. II and Hanihara, K. : Additional features of Ainu dentition. Am. J. Phys. Anthropol. 46 : 13-24, 1977.

14) Sakai, T.: The racial character in dental morphology, In : Anthropology (edited by Anthropol. Soc. Nippon), pp.88-99, Nikkei Science Co., Tokyo, 1984 (In Japanese).

15) Goaz, P. W. and Miller, M. C. III. : A preliminary description of the dental morphology of the Peruvian Indian. J. Dent. Res. 45 : 106-119, 1966.

16) Hanihara, K.: Mongoloid dental complex in the permanent dentition. Proc. VIIIth Int. Congr. Anthropol. Ethnol. Sci., pp. 298-300, Tokyo, 1968. 